\title{
Rumen content characterization of grazing dairy cows
}

\author{
F Martillotti, C Tripaldi, S Puppo, S Terramoccia, F Grandoni
}

Istituto Sperimentale per la Zootecnia, Via Salaria, 31, 00016 Monterotondo SC, Rome, Italy

The characterization of ruminal parameters can be useful in evaluating feeds, including pasture, on the basis of nutrients supplied to animals. The rumen undegradable protein is the portion of total dietary protein available in the small intestine.

Three fistulated Friesian dairy cows were grazed on grass ( $F$ arundinacea); after $15 \mathrm{~d}$ adaptation, samples of herbage were collected, chopped $(2.5 \mathrm{~mm})$, weighed $(30 \mathrm{~g})$ in nylon bags and incubated at 8:00, 12:00, 16:00, 20:00, 24:00, $4: 00 \mathrm{~h}$ in the rumen. The zero time incubation corresponded to $8: 00 \mathrm{~h}$ and the final time incubation to $4: 00 \mathrm{~h}$. At the same times, VFA, $\mathrm{pH}$, buffer capacity $(\mathrm{BC})$ to $\mathrm{pH} 7$ and $\mathrm{pH} 4$ (on 2 different samples) and $\mathrm{NH}_{3}$ contents were determined on filtered rumen fluid. The total microbial number was determined on whole rumen content on Petri dishes in Leedle et al (1982) com. plete medium; the fungi enumeration was made using the Joblin roll-bottle method (1981).

As in table I, the $\mathrm{NH}_{3}$ content of the first 3 samples was significantly higher than the other 3 . VFA content decreased with time but only the first value was significantly higher than the last 2; $\mathrm{pH}$ increased with time and the first 3 values were significantly different from the last; obviously an opposite trend was given by the BC. The highest value of total microbial number was observed at 4:00 $\mathrm{h}$ which was significantly higher than the values recorded at 12:00, 16:00 and 24:00 $\mathrm{h}$. The highest amount of fungi was recorded at 8:00 $\mathrm{h}$. The degradability (\%; deg) results of CP and NDF were significantly different each other, except for the last 2. The $\mathrm{NH}_{3}$ and VFA contents were lower when it was dark and consequently the power of equivalent $\mathrm{H}^{+}$diminished as the $\mathrm{pH}$ increased because of minor presence of VFA. The total microbial number was lower at 12:00 and 16:00 $\mathrm{h}$ when the uptake of forage increased and diluted the concentration of ruminal mass. The high $\mathrm{NH}_{3}$ and VFA content in the rumen fluid at 8:00,12:00 and 16:00 $\mathrm{h}$ showed a major availability of $\mathrm{N}$ and carbohydrates during the daylight hours of grazing.

Research supported by NRC, Italy, Spec proj RAISA-Subproj n 3 paper $n 1007$.

Table I. Chemical analyses (\% rumen fluid), total microbial number (celis $\times 1010 / \mathrm{g}$ dried rumen content), fungi number (cells $\times 105 / \mathrm{g}$ dried rumen content), CP and NDF deg (\%).

\begin{tabular}{|c|c|c|c|c|c|c|c|c|}
\hline & $8: 00 \mathrm{~h}$ & $12: 00 h$ & $16: 00 h$ & $20: 00 \mathrm{~h}$ & $24: 00 h$ & $4: 00 h$ & Mean & RMSE \\
\hline $\mathrm{NH}_{3}(\mathrm{mmol})$ & $2.33^{\mathrm{Aa}}$ & $2.13^{\mathrm{Aa}}$ & $2.19 \mathrm{Aa}$ & $1.44^{b}$ & $1.20^{B}$ & $1.00^{B}$ & 1.72 & 0.35 \\
\hline VFA (mmol) & $10.13^{a}$ & $9.15^{a b c}$ & $9.47^{\mathrm{ab}}$ & $8.58 \mathrm{abc}$ & $6.62^{b c}$ & $6.02^{c}$ & 8.33 & 1.88 \\
\hline $\mathrm{pH}$ & $6.66^{\mathrm{bc}}$ & $6.60^{b c}$ & $6.39 \mathrm{Cc}$ & $6.77^{a b c}$ & $7.05^{a b}$ & $7.23^{\mathrm{Aa}}$ & 6.78 & 0.26 \\
\hline $\mathrm{BC}(\mathrm{meq} \mathrm{H})$ & $12.98^{a}$ & $12.70^{a b c}$ & $13.26^{a}$ & $12.49 \mathrm{abc}$ & $12.13^{b c}$ & $12.04^{c}$ & 12.60 & 0.51 \\
\hline Total microbial No & 3.33АВ & $1.38 \mathrm{C}$ & $1.92 \mathrm{Cc}$ & $3.60 \mathrm{AB}$ & $3.02^{\mathrm{Bb}}$ & 3.97Aa & 2.87 & 0.49 \\
\hline Fungi No & $4.50^{A}$ & $0.52^{\mathrm{B}}$ & $0.58^{8}$ & $0.42^{\mathrm{B}}$ & $0.61^{\mathrm{B}}$ & $0.68^{B}$ & 1.22 & 0.23 \\
\hline Deg CP & $43.0 \mathrm{Ee}$ & $49.6^{D d}$ & $73.6 \mathrm{Cc}$ & $80.5^{8 b}$ & $87.3^{\mathrm{Aa}}$ & $88.2^{\mathrm{Aa}}$ & 70.4 & 3.17 \\
\hline Deg NDF & $21.7 \mathrm{E}$ & $40.6^{\mathrm{D}}$ & $62.3^{\mathrm{C}}$ & $67.7^{\mathrm{B}}$ & $73.1^{\mathrm{A}}$ & $74.5^{A}$ & 56.7 & 2.02 \\
\hline
\end{tabular}

A, B, C, D, E $P \leq 0.01 ; \mathrm{a}, \mathrm{b}, \mathrm{c}, \mathrm{d}, \mathrm{e} P \leq 0.05$. 